\title{
Thermally Stable Al-Fe Based Alloys Produced from Secondary Materials
}

\section{Jan Kříž, Pavel Novák}

University of Chemistry and Technology, Prague, Department of Metals and Corrosion Engineering, Technická 5, 166 28 Prague 6, Czech Republic, krizj@vscht.cz, panovak@vscht.cz

Aluminium alloys are characterized by favourable properties, e.g. low density, specific tensile or electric and thermal conductivity. The problem with conventional aluminum alloys is their low thermal stability. According to previous published work, transition metals such as e.g. iron, chromium or nickel, increase the thermal stability. These metals are often found in aluminum waste as undesirable contamination. In this work, the alloys made of aluminum and cast iron or stainless steel were tested, simulating aluminum waste with a high iron content. The materials were prepared by powder metallurgy - method of rapidly solidified particles. The results showed that these alloys exhibit excellent thermal stability.

Keywords: aluminium, recycling, powder metallurgy

\section{Acknowledgement}

This research was carried out with the financial support of the Czech Science Foundation, project P108/12/ G043.

\section{References}

[1] CHEN, CH., SUN, B., WANG, J., SHU, D., LI, P., XUE, L. (2011). A Novel Method to Remove Iron Impurity from Aluminum. In: Materials Transactions, Vol. 52, No. 8, pp. 1629-1633.

[2] HURTALOVÁ, L., TILLOVÁ, E. (2013). Elimination of the negative effect of Fe-rich intermettallic phases in secondary (recycled) aluminium cast alloy In: Manufacturing Technology, Vol. 13, No. 1, pp. 44-50.

[3] KRATOCHVÍL, P. (2008). The history of the search and use of heat resistant Pyroferal@ alloys based on FeAl. In: Intermetallics, pp. 587-591.

[4] VOJTĚCH, D. (2006). Kovové materiály, pp. 185, Vysoká škola chemicko-technologická v Praze, Prague. ISBN 80-7080-600-1.

[5] TASHLYKOVA; BUSHKEVICH; et al. (2008). Structural and phase analysis of rapidly solidified Al- Fe alloys. Journal of Surface Investigation. X- ray, Synchrotron and Neutron Techniques, pp. 310-316.

[6] KARAKÖSE, E., et al. (2011). Structural investigations of mechanical properties of Al based rapidly solidified alloys. In: Mater. Des., vol. 32, pp. 4970-4979.

[7] CAHN, R., HAASEN, P., CRAMER, E. (1991). Processing of metals and alloys. In: Materials Science and Technology, vol. 15.

[8] MICHALCOVÁ, A., VOJTĚCH, D. (2012). Structure of rapidly solidified aluminium alloys. In: Manufacturing Technology, Vol. 12, No. 13, pp. 166 - 169. 